\title{
A Lifetime Pursuit of a Sports Nutrition Practice
}

\author{
KELLY ANNE ERDMAN, MSc, RD, CSSD ${ }^{a}$
}

${ }^{a}$ Canadian Sport Institute Calgary, University of Calgary Sport Medicine Centre, Calgary, AB

\begin{abstract}
Sports nutrition in Canada has significantly evolved over the years from providing fundamental training dietary advice to applied precise assessment of nutritional status in a variety of settings, especially with the establishment of Canadian Sport Institutes and Centres across Canada. This progression has enhanced the level of dietary support to manage athletes' nutrition in a holistic perspective. Athletes are now educated about food fundamentals (acquiring foods, menu planning, preparing, food safety), personal accountability of hydration and energy monitoring (urinary and body weight assessments), individualized supplementation protocols, and customized nutrition for variable daily training environments according to their Yearly Training Plan. Sport dietitians are an important member of Integrated Sport Teams where collaboration exists amongst professionals who coordinate the athletes' personalized training and performance programming. Dietitians in sport are encouraged to continue to lobby for nutrition programming at the elite, varsity, provincial, and club levels to ensure that athletes receive accurate guidance from nutrition experts.
\end{abstract}

(Can J Diet Pract Res. 2015;76:150-154)

(DOI: 10.3148/cjdpr-2015-021)

Published at dcjournal.ca on 17 August 2015.

\section{RÉSUMÉ}

Au Canada, la nutrition du sport a énormément évolué au fil des ans. En effet, elle est passée des conseils alimentaires de base pour l'entraînement à l'évaluation précise et appliquée de l'état nutritionnel dans une variété de milieux, en particulier depuis la création des instituts et des centres canadiens du sport partout au Canada. Ce progrès a permis d'améliorer le niveau de soutien diététique et ainsi de gérer la nutrition des athlètes au moyen d'une approche globale. Les athlètes sont maintenant informés sur les bases de l'alimentation (achat des aliments, planification du menu, préparation, salubrité des aliments), la responsabilité personnelle de s'hydrater et de suivre son niveau d'énergie (évaluation du poids corporel et de l'urine), les protocoles de supplémentation personnalisés et la nutrition adaptée aux environnements variables des entraînements quotidiens en fonction de leur plan d'entraînement annuel. Les diététistes du sport sont des membres importants des équipes de sport intégrées, au sein desquelles les professionnels collaborent pour coordonner les programmes personnalisés d'entraînement et de performance des athlètes. Les diététistes qui évoluent dans le milieu du sport sont encouragés à continuer de promouvoir les programmes alimentaires chez les athlètes de niveau élite, universitaire, provincial ou faisant partie d'un club afin qu'ils reçoivent des recommandations appropriées de la part d'experts en nutrition.

(Rev can prat rech diétét. 2015;76:150-154)

(DOI: 10.3148/cjdpr-2015-021)

Publié au dcjournal.ca le 17 août 2015.

\section{INTRODUCTION}

What an honour to be the recipient of the Ryley-Jeffs Memorial Award from Dietitians of Canada, thank you for this recognition and a special thank you to those who nominated me. As a pioneer in the field of sport nutrition I'd like to share a few career highlights as to how this path was forged and describe some of lessons learnt in this 28 -year journey.

\section{Sport as the motivator for my career}

What motivated you to begin your studies in the field of dietetics? What was the compelling force that enticed you to pursue your career? Sport was and still is my primary motivator to study nutrition. By age 11, I began competing in track and field training $12 \mathrm{~h}$ a week through to the start of university. It was after high school when I had my first taste of bike racing. Three years later I was racing for Team Canada.

I had the fortune to compete in 7 World Cycling Championships, with my best results including fourth at the 1990 World Championships, a silver medal at the 1987 Pan American Games, a bronze at the 1990 Goodwill Games, qualified in 2 events at the 1992 Barcelona Olympics, winner of 13
Canadian championships, and then I was inducted into the Alberta Sport Hall of Fame in 1992. The combination of cycling full-time (1985-1992) while simultaneously establishing a sport nutrition private practice seemed a good fit. Throughout my years of racing I was passionate to learn from the practical side of sport nutrition-which I could later apply with other athletes. I experienced first-hand: carb-loading, recovery nutrition, food during training, supplementation, etc.; some lessons learned the hard way!

While sport drove me to dietetics, I almost never followed that route. I am thankful to my parents for many things, but especially for discovering dietetics and encouraging me to pursue this science-based, credible field.

Admittedly, studying nutrition at the University of Alberta was a selfish endeavor to acquire sport nutrition knowledge for my cycling career, with long-term aspirations of working with athletes. I didn't have the opportunity to take sport nutrition undergraduate courses nor did the International Olympic Committee (IOC) sport nutrition diploma exist. In many ways I was "self-taught" in those early years of acquiring knowledge. My first sport nutrition book was Nancy Clark's Sport 
Nutrition Guidebook, initially published in 1987, she's now written her fifth edition [1].

Whenever possible the majority of my undergraduate (University of Alberta) and dietetic internship projects (Edmonton, $\mathrm{AB}$ ) were focused on sport nutrition themes to officially become an unofficial "sports dietitian". I spent an inspiring elective at the University of British Columbia, Sport Medicine Centre, to work alongside dietitian, Lynne Sawchuk. Informal "journal club" gatherings in Edmonton and Calgary with fellow dietitian enthusiasts, Cindy Thorvaldson, Dr. Barb Marriage, Kim Wagner Jones, Diane Hoy, Suzanne Monk Galesloot, and Helga Remple, to name a few, were enjoyable meetings and intellectually stimulating.

There's no better way than to learn from application, especially when it comes to sport nutrition. While preparing for my first long bike race $(150 \mathrm{~km})$ I had just started university and was a rookie for knowledge. Commercial sport bars, such as PowerBar, didn't exist in Canada, and I needed to carry foods in my jersey pockets to go the distance-my solution was: bananas, dried apricots, and a cold baked potato. Two out of 3 of these options require nearly a litre of water to choke down each bite, especially when it's $30^{\circ} \mathrm{C}$ ! Lessons learnt.

\section{Early career after the 1988 Winter Olympic Games}

I moved to Calgary just after they hosted the 1988 Winter Olympic Games; I hoped this city would present sport nutrition opportunities. In the years to follow, this was a good decision. At that time dietitian Helen Bishop MacDonald was in the spotlight in Calgary. She was often the keynote speaker at dietetic events, she helped oversee the food service during the 1988 Olympics, and she had consulted with the Calgary Flames to win their 1 and only Stanley Cup in 1989. She is legendary.

As with every one of us that specializes in a field there are typical phases of our career. Acquiring the knowledge to gain expertise and confidence to work with a specialized clientele is the first step. That fundamental knowledge leads to needs assessments to determine gaps in our specialty area, followed by application of this knowledge to help our clients-typically the bulk of our career journey. Re-evaluating programs and refining nutrition support are on-going processes to enhance our services.

By 1990 I established a full-time private practice at the University of Calgary Sport Medicine Centre. Dietitians, Anne Carlson, Kim Wagner Jones, and Diane Hoy assisted with my practice when cycling training camps and competitions took me out of Calgary-I'm thankful for their support! The building years of my practice provided the opportunity to work with numerous local community and provincial level sports and teams; I often gave more than 100 sport-specific presentations annually from 1990 to 2000 .

Across Canada sport nutrition was beginning to flourish. The Sport Medicine Council of Canada funded the Sport Nutrition Advisory Committee (both no longer exist). This group of Canadian Dietitians was led by Dr. Marielle Ledoux and over the years included Marilyn Booth, Pam Lynch, Pat McCarthy Briggs, Lynne Sawchuk, Rennie Benedict, Dr. Susan Crawford, and Susie Langley. Together we helped develop the extensive sport nutrition resources currently posted on the Coaching Association of Canada website (www.coach.ca) and collaborated to create the sport nutrition curriculum for educating coaches through the Canadian National Coaching Certification Program. Closer to home, the National Coaching Institute-Calgary was established in 1993; decades later I still regularly teach coaches enrolled in our Institute. In 2008 I also developed and continue to deliver sport nutrition curriculum to Sport Performance classes in Calgary high schools.

By 1994 the first National Sport Centre was established, and it was based in Calgary. This centralized Centre was created to provide support services for national teams that base themselves year-round as a training centre; a good fit for winter sports since ongoing funding had been set aside to help maintain the Calgary Olympic legacy venues. My years of sport nutrition knowledge were now put to the test as the first consulting dietitian for several Canadian national teams, namely: men's and women's hockey, long-track and shorttrack speed skating, cross-country and biathlon ski teams, bobsleigh, skeleton, and luge. Sport nutrition support addresses many areas, including the daily training environment, competition nutrition, travel, and fundamental lifestyle education (grocery shopping, menu planning, food budgeting, etc.). It is not uncommon for a young 16 year old to move to Calgary to train with a national development team, yet have limited skills and knowledge regarding how to nutritionally fuel training and competitions.

\section{Sport supplementation}

The National Sport Centre Calgary evolved into the Canadian Sport Centre Calgary and more recently our title is the Canadian Sport Institute Calgary (CSIC). Through on-going needs assessments we've created a number of high-performance initiatives. Our exclusive batch-tested sport supplement program was a result of my Master's thesis (2004) where we explored the dietary supplementation practices, attitudes, and knowledge of Canadian high-performance athletes from across Canada. Since 2006 I have published several articles regarding sport supplementation and dietary intakes of elite Canadian athletes [2-8]. Acknowledging that supplementation prevalence continues to escalate, we created a batchtested supplement program so that athletes could purchase supplements with the lowest risk of inadvertent doping. This program continues to exist and is accessed by athletes and sport dietitians across Canada. Coincidentally, there have been no positive doping outcomes from the last 2 Olympic Games by Canadian athletes; it's possible the batch-tested supplement program has been impactful.

Sport supplementation has been a focus in my practice for many years. In 2008-2010 Susie Langley, RD, and I co-authored an online sports supplements course for the 
Dietitians of Canada in an effort to educate fellow dietitians about supplementation issues, as well as present evidencebased science for current effective supplements [9].

\section{"Fuel for Gold" / "Fuel the Fire"}

Another sport nutrition initiative at the CSIC was the establishment of a midday training recovery meal program for athletes, prepared by an Executive Chef, called "Fuel for Gold". We piloted this program in 2002 before the Salt Lake City Olympics and by 2004 this meal program was extended to a full-time operation. Since 2010, Fuel for Gold has expanded to a full-scale restaurant based at the University of Calgary. We are open full-time selling wholesome meals to students, faculty, staff, the general public, and of course athletes (including varsity athletes). We've expanded to cater athletic events, training camps, and corporate meetings, as well as serving occasional lunch meals to elementary school children. I was tasked to initiate a similar meal program, "Fuel the Fire", for the Calgary Flames in 2006, as I've been a consultant to this professional team since 2003. Currently the Calgary Flames still provide the "Fuel the Fire" meal program to their team on home game days.

\section{Lead dietitian with Hockey Canada}

In the Canadian sport system we have integrated sport teams (ISTs) that act similar to medical rounds in hospital dietetics. ISTs include coaches, a team manager, a high-performance sport director, physiologist, masseuse, physiotherapist, sport psychologist, team physician, sport dietitian, equipment personnel, and possibly a biomechanist. Collaboratively we discuss the needs of each athlete (athletes are not present). Through discussion we describe how, from our unique disciplines, we can make a difference for each athlete. For example, when an athlete is injured the medical team describes the athlete's physical care and treatments. Simultaneously the dietitian would emphasize interventions to enhance the athlete's recovery, minimize loss of muscle and gaining body fat, discuss possible physical limitations to buying and preparing their meals, and consider any emotional eating concerns, often due to depression associated with their injury. IST meetings can be a weekly event.

A career highlight would be working with Hockey Canada over the past 21 years. I am the lead Dietitian for the Canadian Women's Team, in place during the stretch when they won 4 consecutive Olympic gold medals (2002, 2006, 2010, and 2014). For each of these Games the players would centralize in Calgary by August in preparation for the Olympics 6 months later; each of these Games presented with unique nutrition-related concerns.

During our IST meeting for the National Women's Hockey Team in January, 2002, the following nutrition recommendations were expressed in an effort to specifically enhance the team's endurance. I advised them to move their pregame meals closer to game start time (from $4-5 \mathrm{~h}$ prior to $3-4 \mathrm{~h}$ prior), and insisted that every player sip on a sport drink and consume a "bar" between each period. Their performance was enhanced as they finally beat the Americans (had lost 7 previous encounters) for Olympic gold. In 2006 we focused on the prescriptive use of the batch-tested sport supplements. We also provided several "Chef School" culinary teaching events.

With the 2010 Vancouver Games in Canada there was pressure for the Canadian Women's Hockey Team to win at home. Leading up to these Games we hired a chef to provide ready-made meals for players, especially since their level of pre-Olympic physical exhaustion often sacrificed their energy to prepare optimal nutrition. Leading into the 2014 Sochi Olympics a handful of the Women's National Team players had already won a hat-trick of Olympic golds-they were well versed about their nutritional needs, yet we still had several rookies on the team. In August, 2013 at the start of their 2014 Winter Olympic preparations each hockey player received a Dietitians of Canada cookbook (compiled by the phenomenal work of Mary Sue Waisman, RD) to enhance their recipe repertoire [10]. The degree of nutrition support for Team Canada was most diverse in the 2013-2014 season. Nutrition interventions were individualized, players received practical meal and snack advice, personalized supplementation guidance, and recovery nutrition support, plus ongoing blood analysis, body composition assessments, and food records-all as screening for indication of fatigue. A particular proud moment was when my son's Midget AAA hockey team played against the women's Olympic-bound team in November, 2013. In the end Team Canada won the game, as was their usual outcome against the Alberta-based Midget male teams they played in their Olympic preparations. Through all of these Olympic cycles I'm hopeful that these elite female athletes not only learnt about performance nutrition, but that they established life-long skills and knowledge about eating well.

\section{Performance dietitian for the Canadian Olympic Committee}

Working for the Canadian Olympic Committee (COC) as the Performance Dietitian for the 2011 Pan American Games and the 2012 London and the 2014 Sochi Olympic Games was another career highlight. The main role of the Team Canada dietitian at Games is to ensure Canadian athletes have access to their usual high performance (and comfort) foods to perform at their best. This role is less about individual nutrition support and more about the availability of food before, during, and after training and competitions. To be effective in this position requires several pre-Games visits, and meetings with team high-performance directors and team dietitians about athletes' unique nutritional needs (i.e., food allergies, vegans, etc.). We ship Canadian snack-type foods months in advance so they are available in the Canadian Team's Athlete's Lounge at the Games. During the Olympics we ensure that meal service in the main Athlete's Dining Hall is suitable regarding types of food served, food safety and handling, food service 
hours, etc., as well as ensure that foods at competition venues are readily available and served appropriately. Food safety is an ongoing concern at Games to avoid food-borne illness.

The 2011 Pan Am Games food service was horrificathletes were losing weight, the food was tasteless, there were food safety concerns, foods were lacking at venues-basically the worst case scenario. Although we are not allowed to cook in the Athlete's Village we did our best to prepare "hearty" snacks to keep athletes fuelled. That required almost daily grocery shopping to effectively replenish our Athlete's Lounge (not an easy endeavor when every bag is scrutinized through rigorous security check points). The London and Sochi Games' main food service was much better, but still there were daily challenges around meal service hours and availability of competition venue nutrition. Fortunately the COC agreed to bring fellow dietitian, Catherine Naulleau, to help at Sochi-she was based in the Mountain Village while I catered to athletes in the Coastal Village. It was fantastic to have Catherine at the Games-what a great help! We worked $12-16 \mathrm{~h}$ days for 30 days straight and Catherine's presence made all the difference.

\section{Sport nutrition challenges}

Similar to other areas of dietetics there are often challenges in sport nutrition that we encounter when striving to be effective in our role. A common occurrence in sport dietetics is the issue of "pseudo-nutritionists" advising athletes beyond their scope of practice, yet they seem "credible" to the client. Occasionally the athlete discovers that they have been receiving poor advice, but in other cases the "nutrition counsellor" gains clout. Awkwardly, I may challenge the "counsellor" to question their messages. In time, the popularity of the pseudonutritionist often wanes and efficacious nutrition advice prevails. We need to challenge these imposters and promote ourselves as true experts in our field. The new designation, CSSD-Certified Specialist in Sports Dietetics, is imperative for practicing sport dietitians.

Another challenge, especially in private practice, is the task of following up with client care. It can be easy to take on many tasks and projects, but to be thorough with nutrition intervention requires regular follow through. Succession planning is also critical. There needs to be quality progression and a continuum of nutrition specialization to enhance the work that we do. New eyes have new vision, new insight, and creativity to improve what has been created. On a regular basis I meet with a small group of local dietitians who are working with athletes or have aspirations to become a full-time sport dietitian. We share everything from case studies, current journal articles, and food and nutrition trends to counseling and presentation skills. This has been a symbiotic relationship which will benefit high-performance athletes in the end. I am also a preceptor for a few dietetic interns annually to expose them to sport nutrition roles and responsibilities.

\section{Sport dietitian opportunities}

More recently I have been fortunate to represent the Dietitians of Canada as the Canadian author for the upcoming revision of the Nutrition and Athletic Performance Position Paper, an opportunity to be instrumental in dissemination of sport nutrition knowledge.

A long-term goal is to encourage future career opportunities for aspiring Canadian sport dietitians. Currently there are few sport dietitian full-time employment positions in Canada and most of those placements involve working with elite athletes rather than developing athletes, such as at the varsity level. We need to lobby for these sport dietitian placements throughout university and college campuses across Canada, similar to the structure in the United States.

What area of dietetics are you passionate about? What steps are you taking to acquire the knowledge and to continue to be up-to-date as an expert in your field? Do you stay on top of current trends and critique the efficacy of those trends with sound science? In the interdisciplinary teams that you work in, do you regularly promote the inclusion of nutritional support?

I am very grateful that I discovered sport and that eventually led to a career in sport nutrition. I have had several dietetic opportunities over the years that continue to provide employment gratification. Dietitians are well aware how nutrition is impactful for short- and long-term health. When it comes to athletic performances athletes can have the latest pristine equipment, superior coaching, optimal training programs, great fitness and technique, but their fundamental sport performances will always rely on effective fuellingand that is nutrition. As my CSIC colleague, Kelly Drager, has often stated, "athletes train once or twice a day, but they eat 6 or 7 times a day!"

\section{Acknowledgements}

I'd like to acknowledge my nominators: Susie Langley, Kim Wagner Jones, and Carrie Mullin Innes as well as the Dietitians of Canada for recognizing my work as a sports dietitian and the contributions that I have made to sport dietetics in Canada.

Conflict of interest: The author has no conflict of interest to declare.

\section{References}

1. Clark N. Nancy Clark's sports nutrition guidebook. 5th ed. Champaign, IL: Human Kinetics; 2013.

2. Erdman KA, Fung TS, Reimer RA. Influence of performance level on dietary supplementation in elite Canadian athletes. Med Sci Sports Exerc. 2006 Feb;38(2):349-56. PMID: 16531906.

3. Erdman KA, Fung TS, Doyle-Baker PK, Verhoef MJ, Reimer RA. Dietary supplementation of high-performance Canadian athletes by age and gender. Clin J Sport Med. 2007 Nov;17(6):458-64. PMID: 17993788.

4. Tunnicliffe JM, Erdman KA, Reimer RA, Lun V, Shearer J. Consumption of dietary caffeine and coffee in physically active populations: physiological interactions. Appl Physiol Nutr Metab. 2008 Dec; 33(6):1301-10. PMID: 19088792. doi: 10.1139/H08-124.

5. Lun V, Erdman KA, Reimer RA. Evaluation of nutritional intake in Canadian high-performance athletes. Clin J Sport Med. 2009 Sep;19(5):405-11. PMID: 19741314. doi: 10.1097/JSM.0b013e3181b5413b. Erratum in: Clin J Sport Med. 2010 Jan;20(1):71. Dosage error in article text. 
6. Lun V, Erdman KA, Fung TS, Reimer RA. Dietary supplementation practices in Canadian high-performance athletes. Int J Sport Nutr Exerc Metab. 2012 Feb;22(1):31-7. PMID: 22248498.

7. Erdman KA, Tunnicliffe J, Lun VM, Reimer RA. Eating patterns and composition of meals and snacks in elite Canadian athletes. Int J Sport Nutr Exerc Metab. 2013 Jun;23(3):210-9. PMID: 23114732.

8. Wiens K, Erdman KA, Stadnyk M, Parnell JA. Dietary supplement usage, motivation, and education in young, Canadian athletes. Int J Sport Nutr
Exerc Metab. 2014 Dec;24(6):613-22. PMID: 24667342. doi: 10.1123/ ijsnem.2013-0087.

9. Langley S, Erdman KA. Dietary supplements - sports supplements course; 2010. Dietitians of Canada Learning on Demand [cited 2015 June 23]. Available from: http://www.dietitians.ca/Learn/Learning-On-Demand/ lodstoreproduct?guid=a1a6cc3f-9e1f-4b05-8057-7bc20a9e852d

10. Waisman MS. Dietitians of Canada cook! 275 Recipes celebrate food from field to table. Toronto: Dietitians of Canada; 2011. 